\title{
Correlations between Career Prospects and Learning of Pedagogical Students in Can Tho University, Vietnam
}

\author{
Luong Tran, Phuong Thi Bich Nguyen* \\ School of Education, Can Tho University, Viet Nam
}

Received July 21, 2020; Revised October 11, 2020; Accepted October 19, 2020

\section{Cite This Paper in the following Citation Styles}

(a): [1] Luong Tran, Phuong Thi Bich Nguyen, "Correlations between Career Prospects and Learning of Pedagogical Students in Can Tho University, Viet Nam," Universal Journal of Educational Research, Vol. 8, No. 11B, pp. 6273 - 6279, 2020. DOI: 10.13189/ujer.2020.082266.

(b): Luong Tran, Phuong Thi Bich Nguyen (2020). Correlations between Career Prospects and Learning of Pedagogical Students in Can Tho University, Viet Nam. Universal Journal of Educational Research, 8(11B), 6273 - 6279. DOI: 10.13189/ujer.2020.082266.

Copyright $\odot 2020$ by authors, all rights reserved. Authors agree that this article remains permanently open access under the terms of the Creative Commons Attribution License 4.0 International License

\begin{abstract}
Previous studies have confirmed several factors affecting student learning. It is not clear whether there is a correlation between the career prospects and the learning of pedagogical students in Can Tho University, Viet Nam. This research was undertaken to answer the question, 'Is the occurrence of learning of pedagogical students in Can Tho University, Viet Nam related to their career prospects? Questionnaires using a 5-point Likert scale (Croasmun \& Ostrom, 2011) were delivered to 232 pedagogical students in Can Tho University, Viet Nam. The SPSS was used to process the data using frequencies, mean scores, standard deviation, percent, and spearman correlation. The results show that the mean score of future career prospects of students is 3.5474- corresponding to 'become a teacher' level; the average point of the learning of pedagogical students is 3,7699- at an 'often' level. The findings from this study indicate that there is a strong correlation between the career prospects and the learning of pedagogical students in Can Tho University, Viet Nam. The more solid career prospects are, the better students learn. This finding sets out for educational managers who need to ensure a career in teaching for their students after they graduate to improve their learning in university.
\end{abstract}

Keywords Career, Future, Learning, Career Prospect

\section{Introduction}

Learning is the process of acquiring new or existing knowledge, behaviors, skills, values, or preferences (Richard Gross, 2010). Learning is thus an enduring change in behavior, or in the capacity to behave in a given fashion, which results from practice or other forms of experience. Learning involves acquiring and modifying knowledge, skills, strategies, beliefs, attitudes, and behaviors. People learn cognitive, linguistic, motor, and social skills, and these can take many forms (Dale $\mathrm{H}$. Schunk, 2012). Elements of learning include interest in learning, motivation, needs, passion, positivity, independent, active, and creative. Career is the period of time that you spend in your life working or doing a particular thing (Oxford learners dictionaries) or the job or series of jobs that you do during your working life (Cambridge dictionary). The future is a period of time that is to come (Cambridge dictionary). The career prospect is the probability or chance for future success in a profession (Educalingo; Collins dictionary).

Finding the factors that influence student learning is an issue researchers are concerned about. Several studies have focused mainly on factors that affect the learning of students including learning environment (Stein and Wanstreet, 2003; AizanYaacob, et al, 2018), school mean of parent average years of education, student family possession index, student parents' average years of education and student enrolment in the full-day school program (Cuc Nguyen, Patrick Griffina, 2010), parents, peers, print media, financial reasons, interest (Asma Shahid Kazi, Abeeda Akhlaq, 2017), gender (Farhan Alshammari, et al, 2018; Asma Shahid Kazi, Abeeda Akhlaq, 2017; Roberts, et al, 2011), school board professional 
development (Roberts et al, 2011), beliefs and motivation (Aizan Yaacob, et al, 2018), preparation courses and friends (Dilek İlhan Beyaztaş, Nuray Senemoğlu, 2015), psychological, physical, socio-economic and educational factors, change in the pattern of question papers near examination, unfair means in the examination and lack of proper guidance (Saima Rasul, Qadir Bukhsh, 2011), workload and motivation (Fatwa Tentama, Surahma Asti Mulasari, Netty Merdiaty, 2019), and majors (Luong Tran, 2020). Manonmani Devi, et al. (2020) found out that among the skills that graduates today should possess is the ability to produce a performance as expected by the employers.

A study of José Luís Abrantes et al. (2007) revealed the students' perceived learning depends directly on their interest, pedagogical effect, and learning performance and indirectly on the student-instructor interaction, the instructor's responsiveness, course organization, the instructor's likeability/concern, and the student's learning performance. Motivation as the factors that determine a person's desire to do something (Richards et al, 1992), as a combination of effort plus desire to achieve the goal of learning the language plus favorable attitudes towards learning the language (Gardner, 1985). Ari Riswanto, Sri Aryani (2017) found out that the students have a good record if it has a well and motivated as well, and this study concludes their tie's difference between learning motivation and achievement of students on two different courses. Contribution of student achievement is supported by the motivation of students in schools (Heck, 2007; Levpuscek \& Zupancic, 2008; Lee et al, 2013; Ottmar et al, 2015). Passion is simply showing a strong tendency and willingness through spending time and energy on an activity that someone likes or believes that it is important (Carbonneau, Vallerand, Fernet \& Guay, 2008). Passion is identified with hope, loyalty, care, and enthusiasm, which are key features of effective teaching (Day, 2004). Passion is a significant factor that can contribute to student achievement. In addition to being a motivating factor, passion can influence learning and teach positively by creating excitement and action (Hamdi Serin, 2017).

The factors above affecting student learning are relevant to the present. It is not explicit whether career prospects are independent of the learning of pedagogical students. Thus, the present study is examined to test the hypothesis whether there is a correlation between the learning of pedagogical students in Can Tho University, Viet Nam, and their career prospects.

\section{Methodology}

\section{Research hypothesis}

There is no correlation between future career prospects and the learning of pedagogical students.

\section{Study design}

Questionnaires were designed to survey 232 pedagogical students in School of Education, Can Tho University, Viet Nam. The study was implemented from January to February 2019. 7 questions evaluate the learning of pedagogical students and one question evaluates the student's view of career prospects. These questions (items) were designed with a five-point Likert scale (Croasmun\&Ostrom, 2011). The reliability statistics of the questionnaire with Cronbach's Alpha 0,818 for 8 items.

\section{Data analysis}

Students' answers were evaluated based on 05 points of Likert scale (James T. Croasmun\& Lee Ostrom, 2011) and coded by SPSS for windows software 20.0 as follows: Scale $1=1$, Scale $2=2$, Scale $3=3$. Scale $4=4$, Scale $5=5$. Distance Value $=($ Maximum - Minimum $) / \mathrm{n}=(5-1) / 5=$ 0.8 . Thus, the meanings of the scales were defined as: From 1 to $1.8=$ Certainly unemployed/ Never; From 1.9 to $2.6=$ Unemployment/ Seldom; From 2.7 to $3.4=$ Maybe unemployed/ Sometimes; From 3.5 to $4.2=$ Become a teacher/Often; From 4.3 to $5=$ Certainly become a teacher/ always. The SPSS for Windows software was used to process the data collected using frequencies, mean, standard deviation, percent, and spearman correlation.

\section{Survey participants}

Table 1 illustrates the participants information. The participants of the study were randomly chosen.

Table 1. Participants of the study

\begin{tabular}{cccc}
\hline & Items & N & \% \\
\hline \multirow{2}{*}{ Gender } & Male & 156 & 67,29 \\
& Female & 76 & 32,8 \\
\multirow{2}{*}{ Major } & Natural science & 108 & 46,6 \\
& Social science & 124 & 53,4 \\
\multirow{3}{*}{ School year } & 2nd year & 143 & 61,6 \\
& students & 89 & 38,4 \\
\hline Total & 3rd year students & \multicolumn{2}{c}{ 232 participants }
\end{tabular}

\section{Results}

Table 2 indicates that $X=3.5474$ evaluated as 'Become a teacher' level. The highest indicators, from the highest to the lowest, are: Number of students who believe that they "Become a teachers" is the highest with $44 \%$, the second is "Maybe unemployed" with $42.7 \%$, the third as "Certainly become a teacher" with $8.6 \%$, the fourth as "Unemployment" with $3 \%$ and the final as "Certainly unemployed" with $1.7 \%$. Thus, there is nearly half the percentage of "pessimistic" perspectives of students (47\%) who believe that they would "maybe unemployed" $(42,7 \%)$, 
or "unemployment" (3\%), or "certainly unemployed" $(1.7 \%)$, and there is more than half the percentage of "optimistic" perspectives of students (53\%) who believe that they will "become a teacher" (44\%), or "certainly become a teacher" $(8.6 \%)$.

Table 3 shows the total that sig. $>0,05$, which demonstrates that there were no statistical differences in the mean score of future career prospects of pedagogical students between male and female, natural science and social science, 2nd year and 3rd year. Thus, students' gender, majors, and year of study are different but have similar 'outlooks' on future career prospects.

Table 2. The career prospects of students

\begin{tabular}{|c|c|c|c|c|c|c|c|c|}
\hline \multirow{4}{*}{$\begin{array}{l}\text { Future career prospects of } \\
\text { students }\end{array}$} & & \multicolumn{5}{|c|}{ Scale } & \multirow{2}{*}{ Mean } & \multirow{2}{*}{ Standard deviation } \\
\hline & & 1 & 2 & 3 & 4 & 5 & & \\
\hline & $\mathrm{N}$ & 4 & 7 & 99 & 102 & 20 & \multirow{2}{*}{3.5474} & \multirow{2}{*}{.76582} \\
\hline & $\%$ & $1.7 \%$ & $3 \%$ & $42.7 \%$ & $44 \%$ & $8.6 \%$ & & \\
\hline \multicolumn{9}{|c|}{$\begin{array}{c}1=\text { Certainly unemployed; } 2=\text { Unemployment; } 3=\text { Maybe unemployed; } 4=\text { Become a teacher; } \\
5=\text { Certainly become a teacher }\end{array}$} \\
\hline
\end{tabular}

Table 3. The career prospects of pedagogical students (genders, majors and school year)

\begin{tabular}{|c|c|c|c|c|c|}
\hline No. & \multicolumn{2}{|c|}{ Items } & Mean & Standard Deviation & $\begin{array}{c}\text { T- Test } \\
\text { (Sig.) }\end{array}$ \\
\hline \multirow{2}{*}{1} & \multirow{2}{*}{ Genders } & Male & 3.4342 & .82196 & \multirow{2}{*}{.116} \\
\hline & & Female & 156 & .73335 & \\
\hline \multirow{2}{*}{2} & \multirow{2}{*}{ Majors } & Natural science & 3.5741 & .77585 & \multirow{2}{*}{.622} \\
\hline & & Social science & 3.5242 & .75937 & \\
\hline \multirow{2}{*}{3} & \multirow{2}{*}{ School year } & 2nd year & 3.4755 & .80344 & \multirow{2}{*}{.070} \\
\hline & & 3rd year & 3.6629 & 68992 & \\
\hline
\end{tabular}

Table 4. The learning of pedagogical students

\begin{tabular}{|c|c|c|c|c|c|c|c|c|c|c|}
\hline \multirow{2}{*}{ No. } & \multirow{2}{*}{ Learning of students } & & \multicolumn{5}{|c|}{ Scale } & \multirow{2}{*}{ Mean } & \multirow{2}{*}{$\begin{array}{l}\text { Standard } \\
\text { deviation }\end{array}$} & \multirow{2}{*}{ Ranking } \\
\hline & & & 1 & 2 & 3 & 4 & 5 & & & \\
\hline \multirow{2}{*}{1} & \multirow{2}{*}{ Interest in learning } & $\mathrm{N}$ & 1 & 7 & 47 & 158 & 19 & \multirow{2}{*}{3.8060} & \multirow{2}{*}{.63883} & \multirow{2}{*}{2} \\
\hline & & $\%$ & .4 & 3 & 20.3 & 68.1 & 8.2 & & & \\
\hline \multirow{2}{*}{2} & \multirow{2}{*}{ Learning motivation } & $\mathrm{N}$ & 2 & 9 & 48 & 152 & 21 & \multirow{2}{*}{3.7802} & \multirow{2}{*}{.69565} & \multirow{2}{*}{4} \\
\hline & & $\%$ & .9 & 3.9 & 20.7 & 65.5 & 9.1 & & & \\
\hline \multirow{2}{*}{3} & \multirow{2}{*}{ Learning needs } & $\mathrm{N}$ & 0 & 8 & 28 & 167 & 29 & \multirow{2}{*}{3.9353} & \multirow{2}{*}{.61732} & \multirow{2}{*}{1} \\
\hline & & $\%$ & 0 & 3.4 & 12.1 & 72 & 12.5 & & & \\
\hline \multirow{2}{*}{4} & \multirow{2}{*}{ Learning passion } & $\mathrm{N}$ & 3 & 7 & 61 & 128 & 33 & \multirow{2}{*}{3.7802} & \multirow{2}{*}{.77233} & \multirow{2}{*}{4} \\
\hline & & $\%$ & 1.3 & 3 & 26.3 & 55.2 & 14.2 & & & \\
\hline \multirow{2}{*}{5} & \multirow{2}{*}{ Learning positivity } & $\mathrm{N}$ & 0 & 8 & 50 & 154 & 20 & \multirow{2}{*}{3.8017} & \multirow{2}{*}{.63409} & \multirow[b]{2}{*}{3} \\
\hline & & $\%$ & 0 & 3.4 & 21.6 & 66.4 & 8.6 & & & \\
\hline \multirow{2}{*}{6} & \multirow{2}{*}{ Independent learning } & $\mathrm{N}$ & 1 & 7 & 82 & 130 & 12 & \multirow{2}{*}{3.6250} & & \\
\hline & & $\%$ & .4 & 3 & 35.3 & 56 & 5.2 & & .65258 & 6 \\
\hline 7 & Activo lonening & $\mathrm{N}$ & 0 & 9 & 54 & 148 & 21 & & & \\
\hline 1 & Active learnıng & $\%$ & 0 & 3.9 & 23.3 & 63.8 & 9.1 & 3.7802 & $.65 / 26$ & 4 \\
\hline 8 & Creative learning & $\mathrm{N}$ & 1 & 9 & 78 & 126 & 18 & 36509 & 69854 & 5 \\
\hline 8 & Creative learning & $\%$ & .4 & 3.9 & 33.6 & 54.3 & 7.8 & 3.0509 & .09854 & 5 \\
\hline & Total & & & & & & & 3.7699 & .45844 & \\
\hline & & $1=\mathrm{N}$ & er; & 2= Seldom; & $3=$ Som & nes; & $4=$ Often; & $5=$ always & & \\
\hline
\end{tabular}


The Total mean score of leaning is 3.7699 evaluated as 'Often' level. The mean score of items from 3.6250 to 3.9353. There is a similarity in percentage terms. Looking at the range of levels, we find that there is a total of over $60 \%$ of students often and always express interest in learning, learning motivation, learning needs, learning passion, learning positivity, independent learning, active learning, and creative learning in the learning process. The learning needs, learning positivity and learning positivity are expressed by all students. Whereas, there is a number of students who never had an interest in learning with $0.4 \%$, learning motivation with $0.9 \%$, learning passion with $1.3 \%$, independent learning with $0.4 \%$ and creative learning. The highest mean score is "Learning needs" and the lowest mean score is "Independent learning". All the items reach the 'Often' level in the learning of students.

In terms of genders and majors, Table 5 shows the total that sig. $>0,05$, which demonstrates that there were no statistical differences in the mean score of learning of pedagogical students between male and female, natural science, and social science. Thus, students' gender and majors are different, but the learning is similar.
Table 5. The learning of pedagogical students (genders, majors and school year)

\begin{tabular}{|c|c|c|c|c|c|}
\hline No. & \multicolumn{2}{|c|}{ Items } & Mean & $\begin{array}{c}\text { Standard } \\
\text { Deviation }\end{array}$ & $\begin{array}{c}\text { T- } \\
\text { Test(Sig.) }\end{array}$ \\
\hline \multirow{2}{*}{1} & \multirow{2}{*}{ Genders } & Male & 3.8141 & .52856 & \multirow{2}{*}{.306} \\
\cline { 3 - 5 } & & Female & 3.7484 & .42025 & \\
\hline \multirow{2}{*}{2} & \multirow{2}{*}{ Majors } & Natural science & 3.7442 & .51818 & \multirow{2}{*}{.426} \\
\cline { 3 - 5 } & Social science & 3.7923 & .40004 & \\
\hline \multirow{2}{*}{3} & \multirow{2}{*}{$\begin{array}{c}\text { School } \\
\text { year }\end{array}$} & 2nd year & 3.7150 & .43942 & \multirow{2}{*}{.02} \\
\cline { 3 - 5 } & 3rd year & 3.8581 & .47680 & \\
\hline
\end{tabular}

In terms of the school year, with sig. $=0.02$, which demonstrates that there were no statistical differences in the mean score of learning of pedagogical students between 2 nd year and $3 \mathrm{rd}$ year. The mean of the score of learning of 3rd -year pedagogical students is 3,8581 whereas that of the 2 nd -year pedagogical students is 3,7150 . The difference is 0,1431 . 2rd-year pedagogical students' mean score of learning is lower than 3rd- year pedagogical students. This difference is statistically significant. Thus, students' school year is different, their mean score of learning is different. Pedagogical students' mean score of learning increased significantly over the school year.

Table 6. The correlation between career prospects and learning of students

\begin{tabular}{|c|c|c|c|c|}
\hline No. & & Items & & Future career prospects of studen \\
\hline \multirow{3}{*}{1} & \multirow{3}{*}{\multicolumn{2}{|c|}{ Interest in learning }} & Pearson Correlation & $.253^{* *}$ \\
\hline & & & Sig. (2-tailed) & .00 \\
\hline & & & $\mathrm{N}$ & 232 \\
\hline \multirow{3}{*}{2} & \multirow{3}{*}{\multicolumn{2}{|c|}{ Learning motivation }} & Pearson Correlation & $.284^{* *}$ \\
\hline & & & Sig. (2-tailed) & .00 \\
\hline & & & $\mathrm{N}$ & 232 \\
\hline \multirow{3}{*}{3} & \multirow{3}{*}{\multicolumn{2}{|c|}{ Learning needs }} & Pearson Correlation & $.267^{* *}$ \\
\hline & & & Sig. (2-tailed) & 0.00 \\
\hline & & & $\mathrm{N}$ & 232 \\
\hline \multirow{3}{*}{4} & \multirow{3}{*}{\multicolumn{2}{|c|}{ Learning passion }} & Pearson Correlation & $.256^{* *}$ \\
\hline & & & Sig. (2-tailed) & .00 \\
\hline & & & $\mathrm{N}$ & 232 \\
\hline \multirow{3}{*}{5} & \multirow{3}{*}{\multicolumn{2}{|c|}{ Learning positivity }} & Pearson Correlation & $.144^{*}$ \\
\hline & & & Sig. (2-tailed) & .028 \\
\hline & & & $\mathrm{N}$ & 232 \\
\hline \multirow{3}{*}{6} & \multirow{3}{*}{\multicolumn{2}{|c|}{ Independent learning }} & Pearson Correlation & .005 \\
\hline & & & Sig. (2-tailed) & .935 \\
\hline & & & $\mathrm{N}$ & 232 \\
\hline \multirow{4}{*}{7} & \multirow{3}{*}{\multicolumn{2}{|c|}{ Active learning }} & Pearson Correlation & .085 \\
\hline & & & Sig. (2-tailed) & .195 \\
\hline & & & $\mathrm{N}$ & 232 \\
\hline & \multirow{3}{*}{\multicolumn{2}{|c|}{ Creative learning }} & Pearson Correlation & .043 \\
\hline \multirow{2}{*}{8} & & & Sig. (2-tailed) & .512 \\
\hline & & & $\mathrm{N}$ & 232 \\
\hline \multirow{3}{*}{ Total } & \multirow{3}{*}{\multicolumn{2}{|c|}{ Learning of students }} & Pearson Correlation & $.246^{* *}$ \\
\hline & & & Sig. (2-tailed) & .00 \\
\hline & & & $\mathrm{N}$ & 232 \\
\hline
\end{tabular}


The result with $\mathrm{p}<0.05$ the correlation between future career prospects and learning of students was found. For from item 1 to item 5 with sig. $<0.05$ showed that there is a correlation between future career prospects and interest in learning, learning motivation, learning needs, learning passion, learning positivity of students. In which, future career prospects are strongly correlated with interest in learning, learning motivation, learning needs and learning passion, with sig. $=0.00$. Although future career prospects and learning positivity are correlated, this correlation is not strong, with $\operatorname{sig}=0,028$. Whereas, from item 6 to item 8 with sig. $>0.05$ showed that there is no correlation between future career prospects and independent learning, active learning and creative learning of students. Therefore, the hypothesis is rejected.

\section{Discussion}

The factors that affect student learning were found relevant to the present. This study found out the occurrence of learning of pedagogical students in Can Tho University, Viet Nam related to their career prospects.

Table 2 shows that most students believe in becoming teachers in the future in terms of the mean score (Mean = 3.5474; Standard deviation $=.76582$ ). Regarding the percentage indicator, there is still a percentage of students (4.7\%) who determine that becoming a teacher in the future is impossible. $42.7 \%$ of students are unsure whether they will become teachers in the future. This is true of the current situation in Vietnam where there is an excess of teachers (Giáo dục Việt Nam, 2019; Lao động, 2019; VTC, 2018), and in the future, for pedagogical students' career prospects will be not positive (Giáo dục Việt Nam, 2019) which make a large percentage of students have a "pessimistic" perspectives on their career prospects.

Table 4 shows that learning of students including the interest in learning, learning motivation, learning needs, learning passion, learning positivity, independent learning, active learning, and creative learning was implemented often by students in terms of the mean score of items from 3.6250 to 3.9353 , and total mean score $=3.7699$ corresponding to often level. Regarding the percentage indicator, there is still a percentage of students who do not often express interest in learning, learning motivation, learning needs, learning passion, learning positivity, independent learning, active learning, and creative learning in the learning process. There is even a percentage of student never had an interest in learning, learning motivation, learning passion, independent learning, and creative learning. This number of students is very small but deserves attention. These have a certain impact on the learning process, making the learning results not as high as expected, and therefore, negatively affecting the work they will implement in the future.

From Table 6, the study results reject the hypothesis that there is no correlation between future career prospects and the learning of pedagogical students. The results based on T-Test and Spearman Correlation showed that sig. $<0,05$, indicates that there was a correlation between future career prospects and the learning of students. The future career prospects relevant to the future effect on student learning. The more solid future career prospects, the better students learn. Analysis in detail, there was only a correlation between future career prospects and interest in learning, learning motivation, learning needs, learning passion, learning positivity of students. Whereas, the correlation between future career prospects and independent learning, active learning and creative learning of students was no found. This finding matches well with the previous finding that the uncertainty of their prospects in academia lowered their job satisfaction (Inge van der Weijden, et al,. 2015). A few students are unemployed pedagogical students (Laodong, 2019). This is one of the reasons why they lack interest in learning, learning motivation, learning needs, learning passion, learning positivity, independent learning, active learning, and creative learning.

In general, the more solid future career prospects, the better students learn. Therefore, for students to study well, it is necessary to ensure their career after graduation.

\section{Conclusions}

The findings of the study indicate that most pedagogical students believed in their career prospects. They particular indicated an interest in learning, motivation, needs, passion, positivity, independent, active, and creative in the learning process at university. There was a correlation between career prospects and the learning of pedagogical students. The correlation between career prospects, and interest in learning, motivation, needs, passion, and positivity of pedagogical students were found. However, there was no correlation between career prospects and independent, active and creative in learning of pedagogical students. This finding provides a basis for education managers to ensure employment after graduation for pedagogical students to improve the quality of learning for them.

\section{REFERENCES}

[1] Aizan Yaacob, Aspalila bt. Shapii, Alobaisy Ayman Saad, Waleed Mugahed Al-Rahmi, Yahya M. Al-Dheleai, Nor-affandy Yahaya, Qusay Al-Maatouk (2018). Factors affecting students' learning strategies at school. International Journal of Engineering \& Technology, 7 (4), 3703-3709. doi: 10.14419/ijet.v7i4.16885

[2] Ari Riswanto, Sri Aryani (2017). Learning motivation and student achievement: description analysis and relationships both. International Journal of Counseling and Education, Vol.2, No.1, pp. 42-47. DOI: 10.23916/002017026010.

[3] Asma Shahid Kazi, Abeeda Akhlaq (2017). Factors affecting 
students' academic performance. Global Journal of Management and Business Research, Volume 12 Issue 9 Version 1.0

[4] Cuc Nguyen, Patrick Griffina (2010). Factors influencing student achievement in Vietnam. Procedia Social and Behavioral Sciences 2, 1871-1877. doi:10.1016/j.sbspro.20 10.03.1001

[5] Dale H. Schunk (2012). Learning theories: An educational perspective, Allyn \& Bacon, 501 Boylston Street, Boston, MA, 02116. A. ISBN-13: 978-0-13-707195-1/ISBN-10: $0-13-707195-7$

[6] Dilek İlhan Beyaztaş, Nuray Senemoğlu (2015). Learning approaches of successful students and factors affecting their learning approaches. Education and Science, Vol 40, No 179 193-216. DOI: 10.15390/EB.2015.4214

[7] Farhan Alshammari, Reynita Saguban, Eddieson Pasay-an, Ahmed Altheban, Layla Al-Shammari (2018). Factors affecting the academic performance of student nurses: Across-sectional study. Journal of Nursing Education and Practice, Vol. 8, No. 1. Doi:10.5430/jnep.v8n1p60

[8] Fatwa Tentama, Surahma Asti Mulasari, Netty Merdiaty (2019). Factors affecting work stress in university. International Journal of Public Health Science, Vol. 8, No. 3, pp. 381 385. DOI: 10.11591/ijphs.v8i3.18593

[9] Gardner, R. C. (1985). Social psychology and second language learning: The role of attitudes and motivation. London: Edward Arnold.

[10] Giáo dục Việt Nam (2019). Vì sao tuyển dụng giáo viên nơi thiếu vẫn thiếu, nơi thừa vẫn thừa. Available: https://giaoduc.net.vn/giao-duc-24h/vi-sao-tuyen-dung-giao -vien-noi-thieu-van-thieu-noi-thua-van-thua-post202540.gd

[11] Giáo dục Việt Nam (2019). Đào tạo sư phạm ồ ạt làm mất co hội nghề nghiệp, sinh viên lãng phí thanh xuân. Available: https:/giaoduc.net.vn/giao-duc-24h/dao-tao-su-pham-o-at-1 am-mat-co-hoi-nghe-nghiep-sinh-vien-lang-phi-thanh-xuan -post203976.gd

[12] Hamdi Serin (2017). The Role of Passion in Learning and Teaching. International Journal of Social Sciences \& Educational Studies, Vol.4, No.1, 60-63. doi: 10.23918/ijsse s.v4i1p60

[13] Heck, R. H. (2007). Examining the relationship between teacher quality as an organizational property of schools and students' achievement and growth rates. Educational Administration Quarterly, 43(4), 399-432.http://doi.org/10. 1177/0013161X07306452

[14] https://dictionary.cambridge.org/dictionary/english/career

[15] https://educalingo.com/en/dic-en/career-prospects

[16] https://www.collinsdictionary.com/dictionary/english/career -prospects

[17] https://laodong.vn/giao-duc/40000-cu-nhan-su-pham-that-n ghiep-van-co-hang-nghin-thi-sinh-dang-ky-xet-tuyen-vao-n ganh-su-pham-603896.1do

[18] https://www.oxfordlearnersdictionaries.com/definition/engli $\mathrm{sh} /$ career 1 ? $\mathrm{q}=$ career

[19] James T. Croasmun \& Lee Ostrom (2011). Using
Likert-Type Scales in the Social Sciences. Journal of Adult Education. Volume 40, Number 1.

[20] José Luís Abrantes, Cláudia Seabra, Luís Filipe Lages (2007). Pedagogical affect, student interest, and learning performance. Journal of Business Research 60 (2007) 960 964. DOI: 10.1016/j.jbusres.2006.10.026

[21] Inge van der Weijden, Christine Teelken, Moniek de Boer \& Mariske Drost (2015). Career satisfaction of postdoctoral researchers in relation to their expectations for the future. The International Journal of Higher Education Research, Vol 70, No 3. doi:10.1007/s10734-015-9936-0.

[22] Lao động (2019). Vì sao quá nhiều cử nhân sư phạm thất nghiệp? Available: https://laodong.vn/giao-duc/vi-sao-quanhieu-cu-nhan-su-pham-that-nghiep-731421.ldo

[23] Lao động (2018). 40.000 cử nhân sư phạm thất nghiệp, vẫn có hàng nghìn thí sinh đăng ký xét tuyên vào ngành sư phạm. Available:

https://laodong.vn/giao-duc/40000-cu-nhan-su-pham-that-n ghiep-van-co-hang-nghin-thi-sinh-dang-ky-xet-tuyen-vao-n ganh-su-pham-603896.ldo

[24] Lee, J., Liu, X., Amo, L. C., \& Wang, W. L. (2013). Multilevel linkages between state standards, teacher standards, and student achievement: Testing external versus internal standards-based education models. Educational Policy, 28(6), 780-811. http://doi.org/10.1177/0895904813 475708

[25] Levpuscek, M. P., \& Zupancic, M. (2008). Math achievement in early. Journal of Early Adolescence, XX(X), 1-30. http://doi.org/10.1177/0272431608324189

[26] Luong Tran (2020). Misbehavior of Pedagogical Students in Classroom: A Case Study of Can Tho University in Viet Nam, Universal Journal of Educational Research, 8(7): 2772-2777. DOI: 10.13189/ujer.2020.080704

[27] Manonmani Devi, M. A. R Annamalai, Saravanan P. Veeramuthu (2020). Literature Education and Industrial Revolution 4.0. Universal Journal of Educational Research, 8(3), 1027 - 1036. DOI: 10.13189/ujer.2020.080337.

[28] Ottmar, E. R., Rimm-Kaufman, S. E., Larsen, R. a., \& Berry, R. Q. (2015). Mathematical Knowledge for Teaching, Standards-Based Mathematics Teaching Practices, and Student Achievement in the Context of the Responsive Classroom Approach. American Educational Research Journal, 52(4), 787-821. http://doi.org/10.3102/000283121 5579484

[29] Richard Gross (2010). Psychology: The Science of Mind and Behaviour 6E, Hachette UK, ISBN 978-1-4441-6436-7.

[30] Richards, J.C., Platt, J., \& Platt, H. (1992). Longman dictionary of language teaching and applied linguistics. London: Longman.

[31] Roberts, Kerry L., Sampson, Pauline M. (2011). School board member professional development and effects on student achievement. International Journal of Educational Management, v25 n7 p701-713

[32] Saima Rasul, Qadir Bukhsh (2011). A study of factors affecting students' performance in examination at university level. Procedia Social and Behavioral Sciences 15, 20422047. doi:10.1016/j.sbspro.2011.04.050 
[33] Stein, D. S. and C. E. Wanstreet (2003). Role of social presence, choice of online or face-to-face group format, and satisfaction with perceived knowledge gained in a distance learning environment. Midwest Research to Practise Conference in Adult, Continuing and Community
Education.

[34] VTC (2018). Bộ Giáo dục lý giải tình trạng thừa thiếu giáo viên. Available:https://vtc.vn/giao-duc/bo-giao-duc-ly-giaitinh-trang-thua-thieu-giao-vien-ar432006.html 